round about them. I know that every country editor does a thousand things every year to promote both individual and the public welfare, for which there is no other reward than that which arises from the consciousness of having done well whatever his hands have found to do. And so they will continue to act, in guarding with untiring vigilance the best interests of the intelligent and enterprising people among whom their lot is cast.

\title{
ANOTHER REVOLUTIONARY VETERAN GONE
}

Died, in the city of Wilmington, on the 29th ult., Captain David Kirkpatrick, in the eighty-seventh year of his age. $\mathrm{He}$ was the last surviving commissioned officer of the Delaware Line.

Never was old age more beautifully portrayed than in the deceased; the gentleness of manners, the benign expression of his eye, the quiet tones of his voice, rendered him an object of deep interest, and never was filial piety more lovely than was exhibited in the comforts which surrounded this aged veteran. The tender hands of affectionate children had long "Rocked the cradle of declining age," and the blessing of God will rest on his posterity, "because they did rise up before the hoary head of their father and honored him in his old age."-Missouri Republican, St. Louis, June 15, 1839. (In the newspaper collection of the Historical Department of Iowa.) 
Copyright of Annals of Iowa is the property of State of Iowa, by \& through the State Historical Society of Iowa and its content may not be copied or emailed to multiple sites or posted to a listserv without the copyright holder's express written permission. However, users may print, download, or email articles for individual use. 